\title{
Big Five personality trait differences between students from different majors aspiring to the teaching profession
}

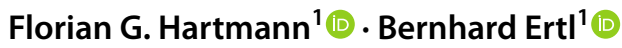

Accepted: 14 November 2021

(c) The Author(s) 2021

\begin{abstract}
Person-Environment fit theories claim that students choose their academic path according to their personality. In this regard, teacher candidates are of special interest. On the one hand, they all make the same choice to enroll in a teacher education program. On the other hand, they make different choices with respect to the subjects they are going to teach. If the PersonEnvironment fit approach also applies to the selection regarding teacher candidates' subject areas, teacher candidates from different majors might have different personality traits and as a result, different starting conditions for becoming a successful teacher. Such differences need to be taken into account by teacher education in order to create programs that allow teacher candidates from different majors to equally succeed. Therefore, the current study investigates to what extent personality group differences across majors occur within the population of teacher candidates. Using data from a large-scale study, the Big Five personality traits of 1735 female and 565 male teacher candidates were analyzed, with teacher candidates compared to male $(\mathrm{n}=1122)$ and female $(\mathrm{n}=1570)$ students who studied the same major but who did not intend to become teachers. Unlike previous studies, academic majors were not grouped into few broad categories, but eight different majors were distinguished. The results indicate that teacher candidates are more extraverted than their non-teaching counterparts. In addition, personality trait differences between teacher candidates from different majors could be observed. The results are discussed as they relate to the recruitment and training of future teachers.
\end{abstract}

Keywords Teacher candidates · Big Five · Personality trait differences · Academic majors · Gender differences · Entry characteristics

\section{Introduction}

Teacher candidates' personality traits are seen as important entry characteristics influencing their college studies and success as teachers. According to the COACTIV model (Kunter et al., 2013a, b), personality traits such as the Big Five (Goldberg, 1990; McCrae \& John, 1992) determine how teacher candidates adopt learning opportunities (see also Klassen \& Kim, 2019; Roloff Henoch et al., 2015) and how far they gain professional competence that fosters their performance and effectiveness in the classroom (Baier et al., 2019; Fauth et al., 2019; Kunter et al., 2013b).

Florian G. Hartmann

florian.hartmann@unibw.de

1 Institute of Educational Sciences, Universität der Bundeswehr München, Werner-Heisenberg-Weg 39, 85577 Neubiberg, Germany
According to Person-Environment fit theories, students choose their academic majors in correspondence to their personality characteristics (Holland, 1997; Su et al., 2015), a hypothesis that could be confirmed by several studies (Kaufman et al., 2013; Vedel, 2016). From this perspective, teacher candidates are a special group of students since they not only decide to enroll in a teacher education program but also choose a particular subject area they are going to teach (e.g. languages, economics, or math). If teacher candidates choose their subject areas due to their personalities, teacher candidates in different subjects have different personality traits (such as emotional stability or conscientiousness) and, as a result, different personal resources for mastering their studies and for becoming successful teachers (Kunter et al., 2013a, b). Since personality traits such as extraversion and conscientiousness predict desirable outcomes with respect to the teaching profession (Bastian et al., 2017; Kim et al., 2019; Roloff et al., 2020), personality trait differences between teacher candidates need to be disclosed so 
that teacher education programs can take them into account, e.g. by setting different priorities for different subject areas. For example, there are indications that majors of arts and humanities attract students that score low on conscientiousness (Vedel, 2016). If this holds true for the subject areas of teacher candidates as well, teacher education could focus on the promotion of conscientiousness regarding teacher candidates in subjects of arts and humanities by implementing appropriate evidence-based trainings (Javaras et al., 2019).

Studies comparing teacher candidates from different subject areas hardly found any personality trait differences but grouped teacher candidates from quite diverse subject areas into few broad categories like STEM and non-STEM fields (e.g. Roloff Henoch et al., 2015). Previous research indicates (Ertl \& Hartmann, 2019; Su \& Rounds, 2015) that findings with this kind of limited analytic strategy are likely to blur major-specific group differences regarding dispositional traits, which is why scholars suggest to analyze majors or subject areas in greater detail (Nguyen et al., 2016).

Several other aspects should be taken into account when personality traits of teacher candidates are analyzed. Considering previous studies, it is necessary to control for gender, as personality differences between males and females have been consistently reported (Feingold, 1994; Kajonius \& Johnson, 2018). Moreover, reference groups are needed to reveal teacher-specific characteristics, i.e. differences should be identified between students who study the same major but do not aspire to the teaching profession (Roloff Henoch et al., 2015). Finally, personality traits of teachers should be investigated using a framework that is integrative and based on evidence, just as the Big Five framework offers a common basis for accumulating the findings from different studies (Göncz, 2017; Kim et al., 2019).

This study investigates the extent to which teacher candidates from different majors show (un-)favorable personality characteristics at the beginning of their teacher education. Its investigation uses the data from a large-scale study to analyze the Big Five personality traits of teacher candidates across eight different majors. Male and female teacher candidates are compared to male and female students who study the same major but do not intend to become teachers. By taking a differentiated look at teacher candidates' personal entry characteristics, the study contributes to the question how far discipline-specific personality trait differences need to be taken into account in order to "create teacher education programs that are effective in enabling teachers to acquire the knowledge, skills, and dispositions that will allow them to succeed" (Darling-Hammond et al., 2005, p. 390).

Since the current study uses the Big Five framework, in the following, this personality concept is first presented in general, before it is discussed in the teaching context including the respective empirical findings. Subsequently, the relation of the Big Five to the choice of a subject area and to gender, as found in previous studies, are discussed since those relations could also appear within the population of pre-service teachers.

\section{Big Five}

Personality traits are by definition relatively stable dispositions expressed through behavior, thinking, and emotional patterns (Costa et al., 2019). Unlike the earlier stages of personality psychology that featured an overwhelming amount of different personality concepts and measurement instruments, the Big Five are now the predominant framework for investigating personality traits, enabling the comparison and systematic review of findings regarding personality trait differences (John et al., 2008). Originally derived from the natural language people use to describe themselves and other people, the Big Five can be understood as broad personality categories represented by five dimensions: neuroticism (attributes: anxious, nervous, tense); extraversion (attributes: active, sociable, assertive); openness (attributes: curious, cultured, imaginative); agreeableness (attributes: trustful, altruistic, cooperative); and conscientiousness (attributes: reliable, organized, task-oriented). ${ }^{1}$ There are several instruments for measuring the Big Five, including the 240-item NEO-PI-R (Costa Jr. \& McCrae, 1992), the 60-item NEOFFI (Costa Jr. \& McCrae, 1989, 1992), or the 44-item Big Five Inventory (BFI; John et al., 1991). Along with these relatively extensive questionnaires, there are also very short instruments such as the BFI-10 (Rammstedt \& John, 2007) that was simultaneously constructed in both English and German, comprising of only two items per dimension, which is suitable for the use in large-scale studies (Wohlkinger et al., 2011), and has satisfactory psychometric characteristics (e.g. retest reliabilities for the German population given a 6-week interval range from $\mathrm{r}_{\mathrm{tt}}=.66$ to $\mathrm{r}_{\mathrm{tt}}=.87$; Rammstedt \& John, 2007, p. 206). To be sure, these kinds of short questionnaires cannot represent the different facets of the Big Five dimensions as extensive instruments such as the NEO-PI-R do that offer six specific facets for each of the five personality factors.

Along with the Big Five, other personality concepts currently used could serve as a framework for studying teachers' personality such as the Dark Triad of personality (Paulhus \& Williams, 2002), the HEXACO model (Ashton \& Lee, 2007; Ashton et al., 2004), or Holland's (1997) RIASEC model.

\footnotetext{
${ }^{1}$ Because the Big Five are originally based on English terms, it was tested whether its lexical approach can be applied in other languages as well. Based on a project (Angleitner et al., 1990) that John et al. (2008) referred to as a "blue-print study" for research pursuing a similar goal, it was found that the Big Five could clearly be replicated using German expressions (Ostendorf, 1990).
} 
The RIASEC model describes the teaching profession as a work environment emphasizing social interactions. It can therefore be characterized by the dimensions of Social and Enterprising (Holland, 1997; Kaub et al., 2016; O*NET, 2020). According to the meta-analysis by Hurtado Rúa et al. (2019), the RIASEC dimensions are related to the Big Five, with the social dimension sharing variance with agreeableness and both the social and the enterprising dimensions relating to extraversion.

\section{The Effects and Peculiarities of Teachers' Big Five}

Previous studies have indicated that the Big Five dimensions are associated with academic performance (Koschmieder et al., 2018; Poropat, 2009; Richardson et al., 2012; Trapmann et al., 2007; Vedel \& Poropat, 2017) and career success (De Haro et al., 2020; Judge et al., 2002; Ng et al., 2005; Ng \& Feldman, 2014; Seibert \& Kraimer, 2001; Semeijn et al., 2020). Conscientiousness plays a major role for academic achievement (McAbee \& Oswald, 2013; Poropat, 2009; Richardson et al., 2012; Trapmann et al., 2007; Vedel \& Poropat, 2017). Regarding career success, and especially in jobs that include interpersonal interaction, performance is positively related to the personality factors of conscientiousness, agreeableness, and emotional stability (Mount et al., 1998).

Within the teaching context, Bastian et al. (2017) report that teachers' personalities are associated with content knowledge. Furthermore, the results by Roloff et al. (2020) indicate that the agreeableness of future teachers measured at the end of high school predicts later instructional quality, especially in terms of social support. Since this study controlled for cognitive abilities, high school GPA, and teacher education grades, teachers with the same cognitive abilities and the same grades who had higher scores with the personality factor of agreeableness were better able to provide social support to their students. In addition, Baier et al. (2019) were able to show that extraversion predicts learning support and that conscientiousness is related to classroom discipline. Consistent with these findings, the meta-analysis by Kim et al. (2019) revealed that teachers' extraversion and conscientiousness had the strongest relation to teacher effectiveness. Moreover, emotional stability, extraversion, and conscientiousness were negatively related to burnout.

Overall and in accordance with the resilient personality type recurrently found in previous studies (Asendorpf et al., 2001; De Fruyt, 2002; van der Wal et al., 2016; Semeijn et al., 2020), low neuroticism scores and high scores with the remaining dimensions can be seen as favorable personality characteristics, with neuroticism, extraversion, and conscientiousness showing consistent effects (Barrick \& Mount, 1991; Ng et al., 2005; Judge et al., 2002; Judge \& Kammeyer-Mueller, 2007). Agreeableness and extraversion are especially important for jobs involving social interaction (Barrick \& Mount, 1991; Mount et al., 1998).

Studies investigating the effects of personality traits provide important insights into what the favorable characteristics are that could also be used as criteria for the selection and further training of teacher candidates (Klassen et al., 2017; Klassen \& Kim, 2019). In this context, how far teacher candidates differ from other students who study the same major but do not enroll in teacher education is of special interest. This implies the question of whether the "right" people enter the teaching profession. Here, the results of previous studies indicate that teachers differ from their non-teacher counterparts according to several variables. For example, differences between (future) teachers and non-teachers could be observed with respect to vocational interests (Klusmann et al., 2009; Leon et al., 2018; Roloff Henoch et al., 2015), risk aversion (Ayaita \& Stürmer, 2019), and the effects of resilience (Pretsch et al., 2012). Studies focusing on the personality trait differences between teacher candidates and students not intending to become teachers are rare. Klusmann et al. (2009) investigated which factors are predictive for enrolling in a teacher education program. Here, only openness showed predictive validity, in addition to the effects of gender, socio-economic status, cognitive abilities, and vocational interests. Being more open to new experiences decreased the probability of aspiring to the teaching profession. In this study, the social dimension of the RIASEC model, which is known to be related to the Big Five factors of extraversion and agreeableness (Hurtado Rúa et al., 2019), was positively related to enrolling in a teacher education program. Roloff Henoch et al. (2015) indicated the necessity of taking academic majors into account when comparing teacher candidates to other students in terms of their personality characteristics. However, they only differentiated between the broad categories of STEM and non-STEM majors, grouping majors such as mathematics, biology, and computer sciences into one single category. Unfortunately, they did not take into account the personality factor of agreeableness, which is understood as playing a crucial role for careers involving social interaction (Mount et al., 1998). Correspondingly, and as mentioned above, some results indicate that agreeableness affects teachers' instructional quality (Roloff et al., 2020). Regarding the remaining four factors of the Big Five, the study by Roloff Henoch et al. (2015) was able to reveal differences between teacher candidates and other students only within the broad STEM category. Here, STEM teacher candidates were more extraverted than STEM students not intending to become a teacher. Within the broad non-STEM category, teacher candidates did not differ from their non-teaching counterparts with respect to neuroticism, extraversion, openness, and conscientiousness.

In summary, the concept of the Big Five, in the teaching context, has mostly been applied with respect to the 
question of how far personality traits predict teacher outcomes. Less focus has been put on a differentiated investigation of Big Five personality trait differences between (pre-service) teachers from different subject areas. In the next paragraph, therefore, the subject-specific differences that have so far been found outside of the teaching context are discussed.

\section{Personality Trait Differences across Academic Majors}

Studies investigating personality trait differences between students with different academic majors generally suggest that personality traits are related to the choice of major and that students with different majors show different dispositional characteristics. This is why academic majors should be taken into account when analyzing the personality trait differences of teacher candidates.

In her systematic review, Vedel (2016) showed that medium effect sizes were frequently found regarding personality trait differences depending on the academic major. With respect to openness, even large effects could be found on a regular basis. More specifically, students majoring in the arts/humanities, psychology, and political science scored high on openness. Students majoring in the fields of arts/humanities and psychology showed high scores with respect to neuroticism. Regarding the extraversion factor, political science, economics, law, and medical students had high scores. Students majoring in the arts/humanities, psychology, medicine and sciences scored high on the factor of agreeableness, while students in the arts/humanities had low conscientiousness scores. Roloff Henoch et al. (2015) compared STEM students with non-STEM students, finding that STEM students scored lower on extraversion and openness and higher on conscientiousness. Variations between students with different majors could also be revealed using other personality concepts such as the Dark Triad of personality (Litten et al., 2020; Vedel \& Thomsen, 2017).

This makes it reasonable to assume that similar differences emerge when teacher candidates with different majors are compared with respect to their Big Five personality traits. Roloff Henoch et al. (2015) could not find any personality trait differences between teachers with different majors. But as mentioned, they were aiming to only differentiate between two broad major categories and did not consider all of the Big Five dimensions.

As already mentioned in the introduction, a careful investigation of the differences in personality traits necessitates controlling for gender. Therefore, in the next section, gender-specific differences with regard to the Big Five, as indicated by previous studies, are discussed.

\section{Personality and Gender}

The strongest personality trait difference effects between males and females were observed for neuroticism and agreeableness (Feingold, 1994; Kajonius \& Johnson, 2018). Based on the data of a representative German population sample (collected using the BFI-10), gender differences were observed regarding neuroticism, agreeableness, conscientiousness, and openness, with females showing higher scores than males for each (Rammstedt, 2007). Studies examining measurement invariance with respect to gender suggest that these effects are mainly based on construct-relevant gender differences (Danner et al., 2019; Furnham et al., 2013; Samuel et al., 2015), even though there might be some items the reaction on which can be at least partially explained by stereotypical thinking and not only by the latent trait (Ock et al., 2020). For example, men may score higher on the (BFI-10) statement "I see myself as someone who is relaxed, handles stress well" than women even if they have the same value for the latent emotional stability variable (neuroticism), because from a stereotypical standpoint, men are supposed to be in control of their feelings, rendering them less likely to admit that they are unable to handle stress well.

In summary, personality traits appear to impact how teacher candidates take up the learning opportunities offered by teacher education, as well as later teaching effectiveness and teachers' health. Therefore, the Big Five can be seen as important entry characteristics. Previous research indicates that the Big Five are related to gender and academic major choice. Studies investigating the personality traits of teacher candidates from different academic majors have to date been rare, differentiating academic majors on only a very broad level, and making them likely to blur subject-specific differences. A more fine-grained analysis can reveal whether teacher candidates from different majors have different resources (e.g. emotional stability, conscientiousness) for mastering their studies and becoming successful teachers.

\section{The Current Study}

The following investigation took place in Germany and focuses on the personality traits of teacher candidates as important entry characteristics at the beginning of their teacher education program. In comparison to other European countries or the USA, teacher education in Germany is more distinctively divided into two phases that follow one another in time: the academic training and the in-school induction program. The academic training focuses on the acquisition of content knowledge and usually starts with entering university. Here, teacher candidates choose their teaching subjects and attend their subject-specific courses together with students who do not intend to become teachers but have other professional goals (Cortina \& Thames, 
2013). For example, a teacher candidate in the subject area of mathematics participates in the same courses (e.g. linear algebra or analysis) as a mathematics student in a bachelor's degree program pursuing the career of a software developer. ${ }^{2}$

The current study aims to identify teacher-specific characteristics and compares teacher candidates across eight different majors (German language, social sciences, economics, mathematics, physics, chemistry, biology, geography) with students studying the same major but not intending to become teachers. In addition to the teacher-variable (teacher vs. non-teacher) and the academic major, the gender of students is controlled for due to previous studies finding personality traits to be related to all three variables. Most importantly and superior to previous studies, the current examination allows more precise insight into whether teacher candidates differ depending on their major and whether they are likely to have different resources available for mastering their studies and developing into successful teachers who facilitate students' educational success.

The personality of students is studied using the Big Five framework comprising of five different traits: neuroticism (emotional stability), extraversion, openness, agreeableness, and conscientiousness. We aim to investigate two research questions and three hypotheses:

(1) How far do teacher candidates differ with regard to the Big Five personality traits from students who do not aspire to the teaching profession?

The results of previous research suggest that teacher candidates, compared to other students, show lower scores on the personality factor of openness to experience (Klusmann et al., 2009). Since the teaching profession is especially characterized by social interaction, we would also expect teacher candidates to show higher extraversion and agreeableness scores (Barrick \& Mount, 1991; Mount et al., 1998; Roloff Henoch et al., 2015). From this, we derive three hypotheses regarding the differences between teacher candidates and other students with the same major (non-teaching students):

1a) Teacher candidates show higher extraversion scores than non-teaching students.

1b) Teacher candidates show lower openness scores than non-teaching students.

1c) Teacher candidates show higher agreeableness scores than non-teaching students.

Hypotheses 1a) and 1b) are also supported by Holland's (1997) RIASEC model, which understands the teaching

\footnotetext{
2 The courses, however, may be split for different reasons like course size and scheduling issues.
}

profession as characterized by the social dimension, which is positively associated with extraversion and agreeableness (Hurtado Rúa et al., 2019).

(2) To what extent do teacher candidates with STEM majors differ with regard to the Big Five personality traits from teacher candidates with non-STEM majors?

To the best of our knowledge, there are only a few studies regarding personality trait differences between teacher candidates from different majors (e.g. Roloff Henoch et al., 2015). Since these studies hardly found any differences when grouping quite diverse majors into broad subject areas, we refrain from deriving specific hypotheses on this matter in the current study. Vedel (2016) reported major group differences regarding all Big Five dimensions, with openness showing the strongest effects. Within the teaching context, Roloff Henoch et al. (2015) could not find any differences between teachers in two broad academic major categories (STEM vs. non-STEM). Our study is able to show whether this holds true when majors are differentiated within STEM and non-STEM fields. As previous results indicate, substantial variance can be observed within both STEM ( $\mathrm{Su}$ \& Rounds, 2015) and non-STEM fields (Ertl \& Hartmann, 2019) when students' dispositional characteristics are analyzed.

Because men and women differ regarding the Big Five, gender was controlled for in our study (Feingold, 1994; Kajonius \& Johnson, 2018; Rammstedt, 2007). Although this was not our focus, we did in fact expect women to score higher on neuroticism, agreeableness, conscientiousness, and openness (Rammstedt, 2007).

\section{Method}

This investigation uses data of the first-year student cohort (SC5: 12.0.0) from the German National Educational Panel Study (NEPS; Blossfeld et al., 2011). NEPS is a nation-wide panel study in Germany that started in 2010 and has since then longitudinally collected data from six different starting cohorts with a total of about 60,000 respondents. The target population of the SC5 was defined as all first-year students who were enrolled in a public or state-approved institution of higher education in Germany for the first time in the 2010/11 winter term aiming at a Bachelor's degree, a state examination (in medicine, law, pharmacy, or teaching), a diploma or Master's degree (in Protestant theology or Roman Catholic theology) or specific art and design degrees. A random cluster sample was drawn from the target population including an intended oversampling of teacher candidates and students in private higher education institutions. A cluster was defined as the totality of students being enrolled 
in a particular major at a particular institution (e.g., all students studying mathematics at the University of Cologne). This sampling strategy resulted in 444 realized clusters, 52 of which consisted only of teacher candidates (Zinn et al., 2017). Students willing to participate were surveyed starting at the beginning of their studies. Big Five personality traits were assessed in the third wave of the panel between March and August of 2012. Data was collected via computerassisted telephone interviews (FDZ-LIfBi, 2020). All students gave informed consent for participating in the panel.

For the current analysis, academic majors were taken into consideration if teacher candidates could also study them and if they comprised enough students to enable useful quantitative analyses. These conditions were met for German language, social sciences, economics, mathematics, physics, chemistry, biology, and geography. As a consequence, the sample of the current study comprised of 2300 teacher candidates ( $24.57 \%$ males, $75.43 \%$ females) and 2692 students studying the same academic major but not working towards a teacher qualification ( $41.68 \%$ males, $58.32 \%$ females).

Students' personality traits were measured using the items of the BFI-10 (Rammstedt \& John, 2007) which has been proven to have satisfactory psychometric characteristics and to show satisfactory construct validity. It is also highly economic and especially suitable for use in large-scale studies (Rammstedt et al., 2014; Wohlkinger et al., 2011). The scales of the BFI-10 aim to measure the Big Five and comprise of two items per personality dimension. Because it was considered that, particularly with respect to the agreeableness factor, the NEPS data should enable more profound analyzes, a third item was added to this scale (Wohlkinger et al., 2011). Given the attempt to assess the Big Five relatively broadly despite the shortness of the scales (Rammstedt \& John, 2007), and with the exception of agreeableness, all scales showed acceptable internal consistencies based on the sample of the current study (neuroticism: $\alpha=.56$; extraversion: $\alpha=.74$; openness: $\alpha=.54$; agreeableness: $\alpha=.37$; conscientiousness: $\alpha=.54)$. Since internal consistency measured by coefficient alpha (Cronbach, 1951) depends on both the mean inter-item correlation and the number of items per scale (McCrae et al., 2011) and since the BFI10 scales are very short, we additionally report retest reliabilities to evaluate reliability of the Big Five measures in the current study. For this purpose, we considered the Big Five scores of respondents given in wave 10, which were surveyed four years after wave 3 . The retest reliabilities range from $r_{t t}=.53$ to $r_{t t}=.68$ (neuroticism: $r_{t t}=.55$; extraversion: $r_{\mathrm{tt}}=.67$; openness: $r_{\mathrm{tt}}=.68$; agreeableness: $r_{\mathrm{tt}}=.53$; conscientiousness: $r_{t t}=.61$ ) fitting well with meta-analytic findings on the stability of personality traits given the four year interval between the two measurement times (Anušić \& Schimmack, 2016; Low et al., 2005). However, it is important to note that the scale of agreeableness shows the lowest values regarding both reliability measures. This is in line with previous studies indicating that the BFI-10 scale of agreeableness shows relatively low reliability (Rammstedt \& John, 2007; Rammstedt et al., 2014). Using only two items instead of three, with respect to the scale of agreeableness, did not increase internal consistency. Therefore, all three items available for measuring agreeableness were used to calculate scale score as recommended by Rammstedt and John (2007).

Initially, an $8 \times 2 \times 2$ MANOVA was conducted to analyze personality trait differences (study subject $\mathrm{x}$ study program $\mathrm{x}$ gender). Since academic majors are genuinely different regarding the distribution of study program and gender and, because the sample size causes even small effects to be significant, the prerequisites for a MANOVA were violated, meaning these results should be interpreted with caution. Therefore, we focused on the comparison of confidence intervals to analyze mean differences with respect to the Big Five personality traits (see Field et al., 2019). All data analyses were performed using a remote terminal (Remote$\mathrm{NEPS}^{3}$ ) at the Leibniz Institute for Educational Trajectories in Bamberg, Germany, providing a controlled privacy environment for data access. IBM SPSS Statistics (Version 25) was used for all of the statistical analyses. Missing values were excluded listwise for each analysis, which means that the $N$ s vary slightly for the different analyses.

\section{Results}

The following presents the results regarding group differences for each of the Big Five personality traits. First, confidence intervals with respect to gender differences are inspected. Secondly, study program differences are then reported (Research question 1), followed by a deeper look into the characteristics of teacher candidates, taking their academic major into account (Research question 2). Here, we will compare the personality traits of teacher candidates in STEM fields (mathematics, physics, chemistry, biology, geography) with the personality traits of teacher candidates in non-STEM fields (German, social sciences, economics) (c.f. Kaub et al., 2016). These comparisons can reveal whether classifying majors into broad categories is sufficient or whether a more precise differentiation is necessary when investigating the personality traits of teacher candidates.

See Supplements 1 to 5 for the means, standard deviations, and confidence intervals regarding the Big Five personality traits for each group. ${ }^{4}$

\footnotetext{
3 https://www.neps-data.de/en-us/datacenter/dataaccess/remoteneps. aspx

${ }^{4}$ See Supplement 6 for the results of the MANOVA.
} 


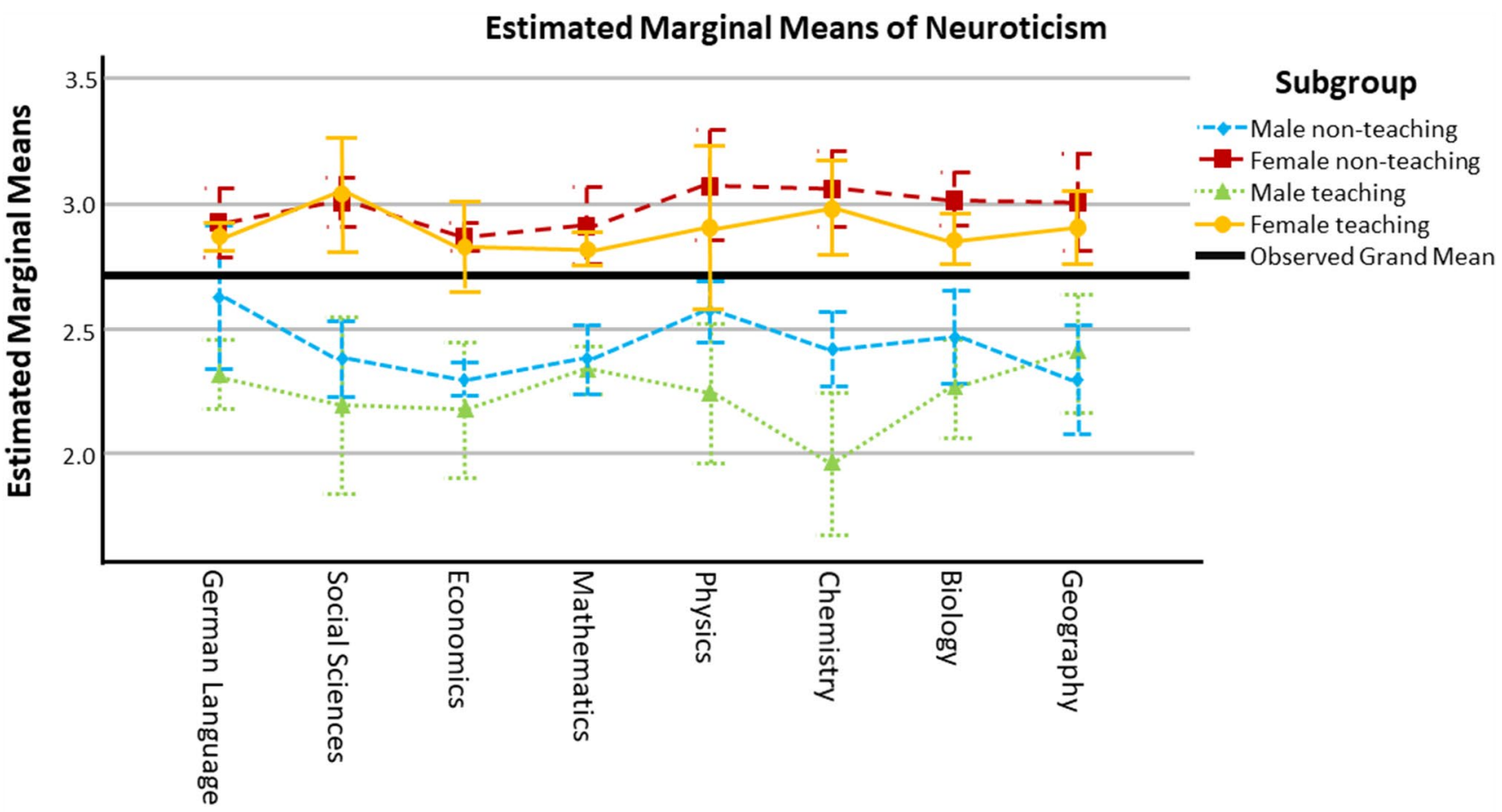

First Study Subject

Error bars: $95 \% \mathrm{Cl}$

Fig. 1 Means and 95\% confidence intervals for the students' neuroticism, for male non-teaching students (blue short dashed line), female non-teaching students (red long dashed line), male teacher candidates

\section{Gender Differences}

Neuroticism Female students generally had higher values than their male counterparts (Fig. 1). One exception relates to German, where male non-teaching students showed a very large confidence interval overlapping with the interval of female non-teaching students. ${ }^{5}$

Extraversion There were no significant differences between male and female students in any of the subjects (see Fig. 2).

Openness With respect to openness, female non-teaching students in economics, physics, and chemistry showed higher values than their male counterparts as well as female teacher candidates in comparison to male teacher candidates in mathematics (see Fig. 3). Apart from this, there were no gender differences.

\footnotetext{
5 Since smaller sample sizes are related to higher standard errors (e.g. Abbott, 2017), the confidence intervals of some groups of students are quite large. This especially applies to male non-teaching students in German language, male teacher candidates in social sciences, male and female teacher candidates in physics, and male teacher candidates in chemistry.
}

(green dotted line), and female teacher candidates (orange solid line) in the different subjects $(\min =1 ; \max =5)$. Tables with the respective values can be found in Supplement 1

Agreeableness With respect to agreeableness, we could identify several gender differences (see Fig. 4). Female teacher candidates showed higher values than male teacher candidates in German, mathematics, and biology. Gender differences were also observed for non-teaching students in economics, mathematics, and chemistry, with females reporting higher agreeableness than males. Again, male students never scored significantly higher than their female counterparts.

Conscientiousness Female students generally showed higher values on the factor of conscientiousness than male students (see Fig. 5). For non-teaching students, these gender differences were significant for economics, mathematics, and biology, and for teacher candidates in German, mathematics, chemistry, biology, and geography.

Overall, the results meet our expectations and are in line with previous research, with females scoring higher on neuroticism, agreeableness, conscientiousness, and openness, and with neuroticism showing the clearest gender differences. 


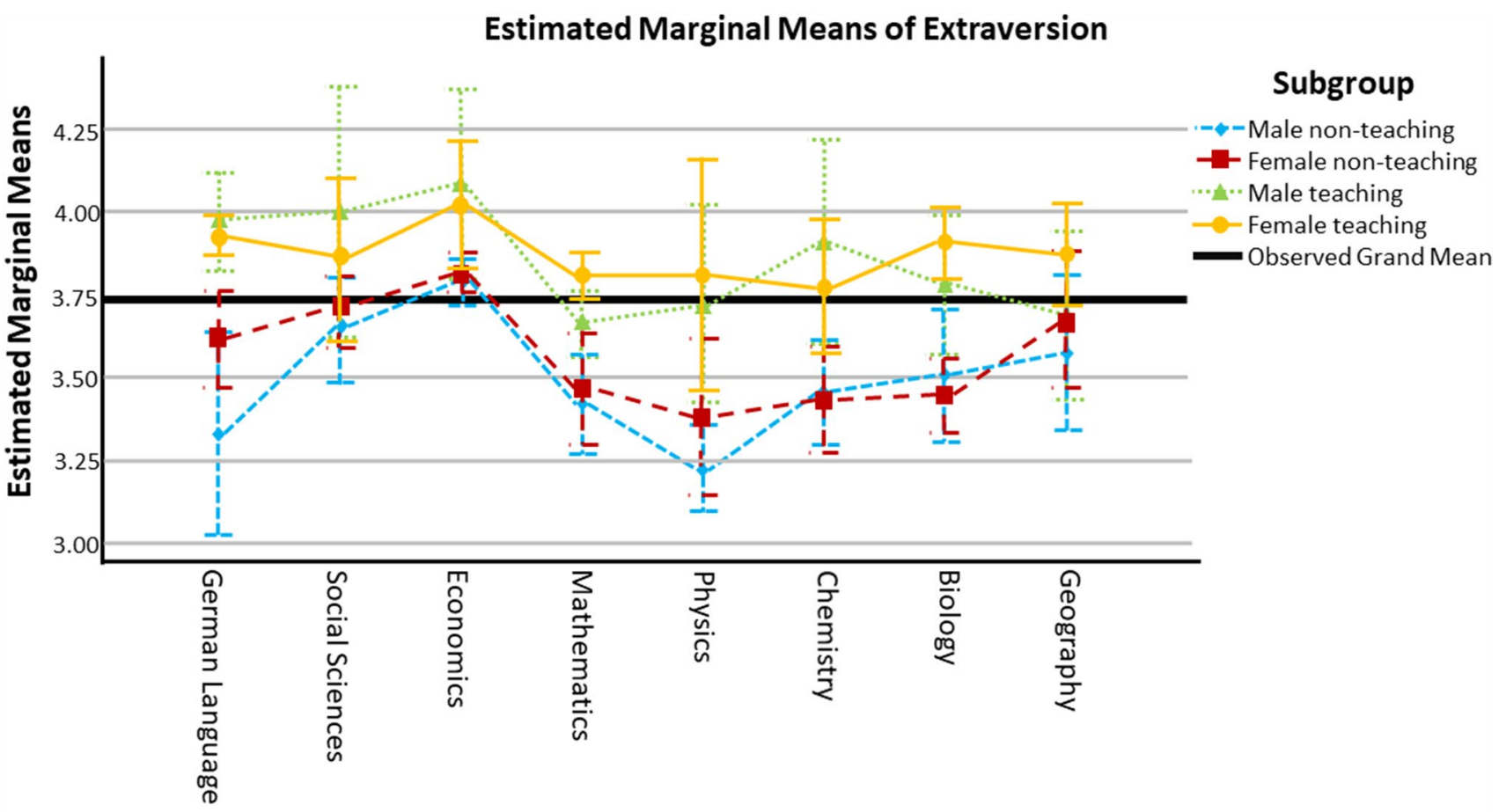

First Study Subject

Error bars: $95 \% \mathrm{Cl}$

Fig. 2 Means and 95\% confidence intervals for the students' extraversion, for male non-teaching students (blue short dashed line), female non-teaching students (red long dashed line), male teacher candidates

\section{Teacher Candidates vs. Non-teaching Students}

Neuroticism Significant differences between non-teaching students and teacher candidates could only be found for chemistry, where male teacher candidates showed lower values than male non-teaching students (Fig. 1).

Extraversion Descriptively, teacher candidates showed higher values in extraversion in all study areas. This difference was significant for teacher candidates in German (males and females), for females in mathematics and biology, as well as for males in physics (see Fig. 2). Hypothesis 1a can partially be confirmed as a result.

Openness The evidence for Hypothesis $1 \mathrm{~b}$ is weak because the differences between teacher candidates and non-teaching students could only be observed for German, where, as expected, female teacher candidates showed less openness than their non-teaching counterparts (see Fig. 3).

Agreeableness Female teacher candidates showed higher agreeableness than female non-teaching students in the non-STEM field of German, and male teacher candidates in the STEM fields of mathematics and physics reported (green dotted line), and female teacher candidates (orange solid line) in the different subjects $(\min =1 ; \max =5)$. Tables with the respective values can be found in Supplement 2

higher agreeableness than their non-teaching counterparts (see Fig. 4). Apart from this, no significant differences were observed. The results partially confirm Hypothesis 1c as a result.

Conscientiousness Significant differences between nonteaching students and teacher candidates could only be revealed for mathematics, with male teacher candidates showing higher values (see Fig. 5).

Overall, extraversion most consistently reveals the expected personality trait differences between teacher candidates and non-teaching students.

\section{Teacher Candidates from Different Majors}

Previous studies only compared teacher candidates' personality from different majors on a very broad level (e.g. STEM vs. non-STEM). The results of our analysis indicate that, because there are some subject-specific differences which are not equal for all STEM or non-STEM fields, this is an insufficient strategy. 


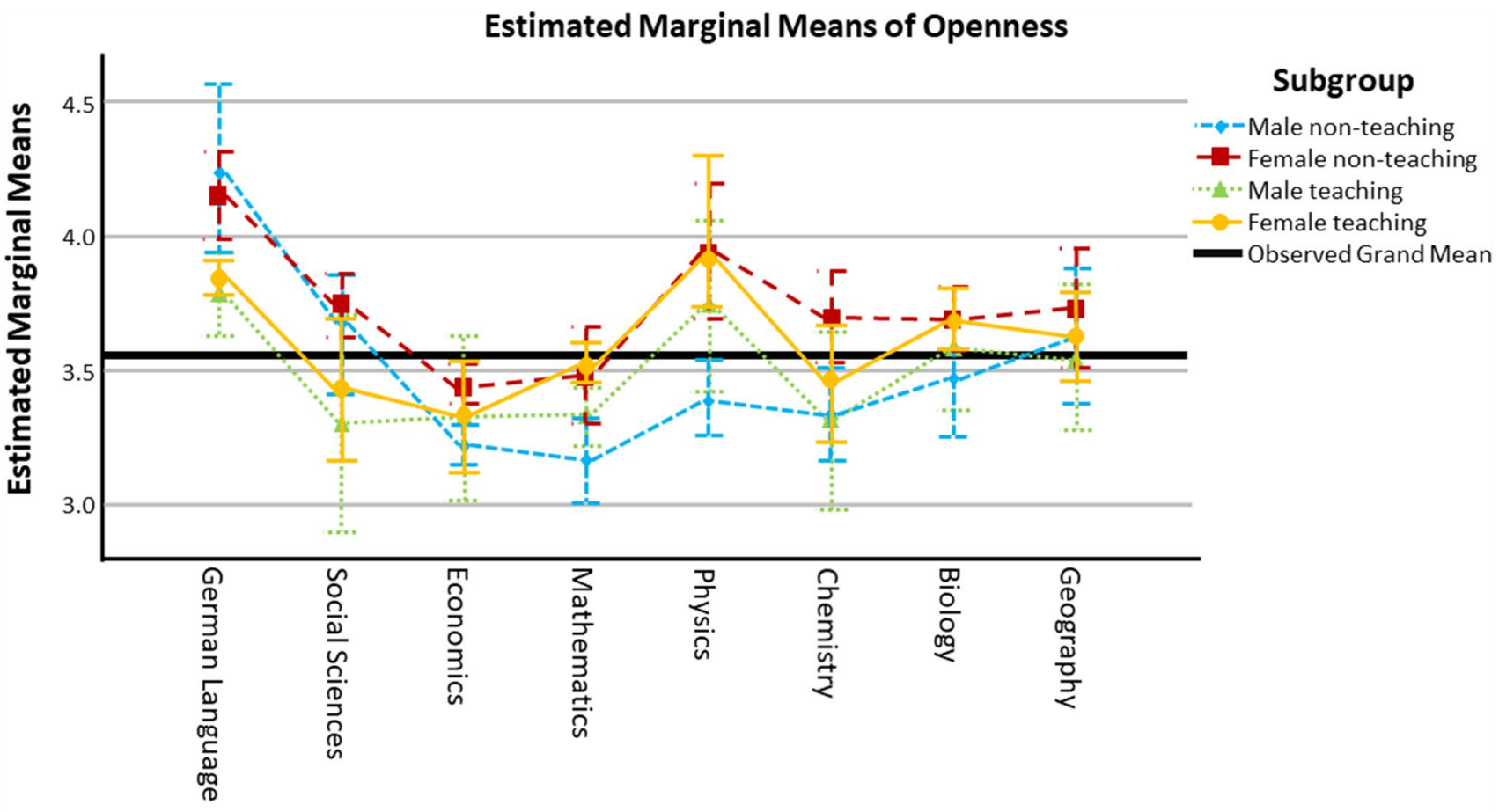

First Study Subject

Error bars: $95 \% \mathrm{Cl}$

Fig. 3 Means and 95\% confidence intervals for the students' openness, for male non-teaching students (blue short dashed line), female non-teaching students (red long dashed line), male teacher candidates

Neuroticism Regarding neuroticism, teacher candidates in all STEM fields did not differ from teacher candidates in all non-STEM fields (see Fig. 1).

Extraversion Inspecting confidence intervals, only male teacher candidates in the STEM field of math showed lower extraversion than male teacher candidates in the non-STEM fields of German language and economics (see Fig. 2). There are no differences when teacher candidates in the STEM field of math are compared to teacher candidates in the nonSTEM field of social sciences. Moreover, teacher candidates in the STEM fields of physics, chemistry, biology, and geography did not differ from teacher candidates in any nonSTEM field; this holds true for both genders.

Openness With respect to openness, teacher candidates in German (male and female) had higher scores than (male and female) teacher candidates in mathematics. Female teacher candidates in German were also more open to new experiences than female teacher candidates in chemistry (see Fig. 3). Conversely, female teacher candidates in the nonSTEM field of economics were less open than female teacher candidates in the STEM fields of physics and biology. (green dotted line), and female teacher candidates (orange solid line) in the different subjects $(\min =1 ; \max =5)$. Tables with the respective values can be found in Supplement 3

Agreeableness Regarding the factor of agreeableness, there is a tendency that teacher candidates in STEM fields show a higher agreeableness than teacher candidates in non-STEM fields (see Fig. 4). This difference was only significant for female teacher candidates in mathematics compared to female teacher candidates in economics, as well as for male teacher candidates in mathematics and physics compared to male teacher candidates in social sciences.

Conscientiousness The analysis of personality trait differences on a fine-grained level reveal that male teacher candidates in the non-STEM field of economics show higher conscientiousness than male teacher candidates in the STEM fields of mathematics, physics, chemistry, and biology, while they show no differences compared to teacher candidates in geography (see Fig. 5).

There were overall few personality trait differences to observe between teacher candidates in STEM fields and teacher candidates in non-STEM fields. Regarding openness, the differences between STEM and non-STEM teacher candidates partly showed in different directions (positive for German compared to mathematics and chemistry, negative for economics compared to physics and biology). 


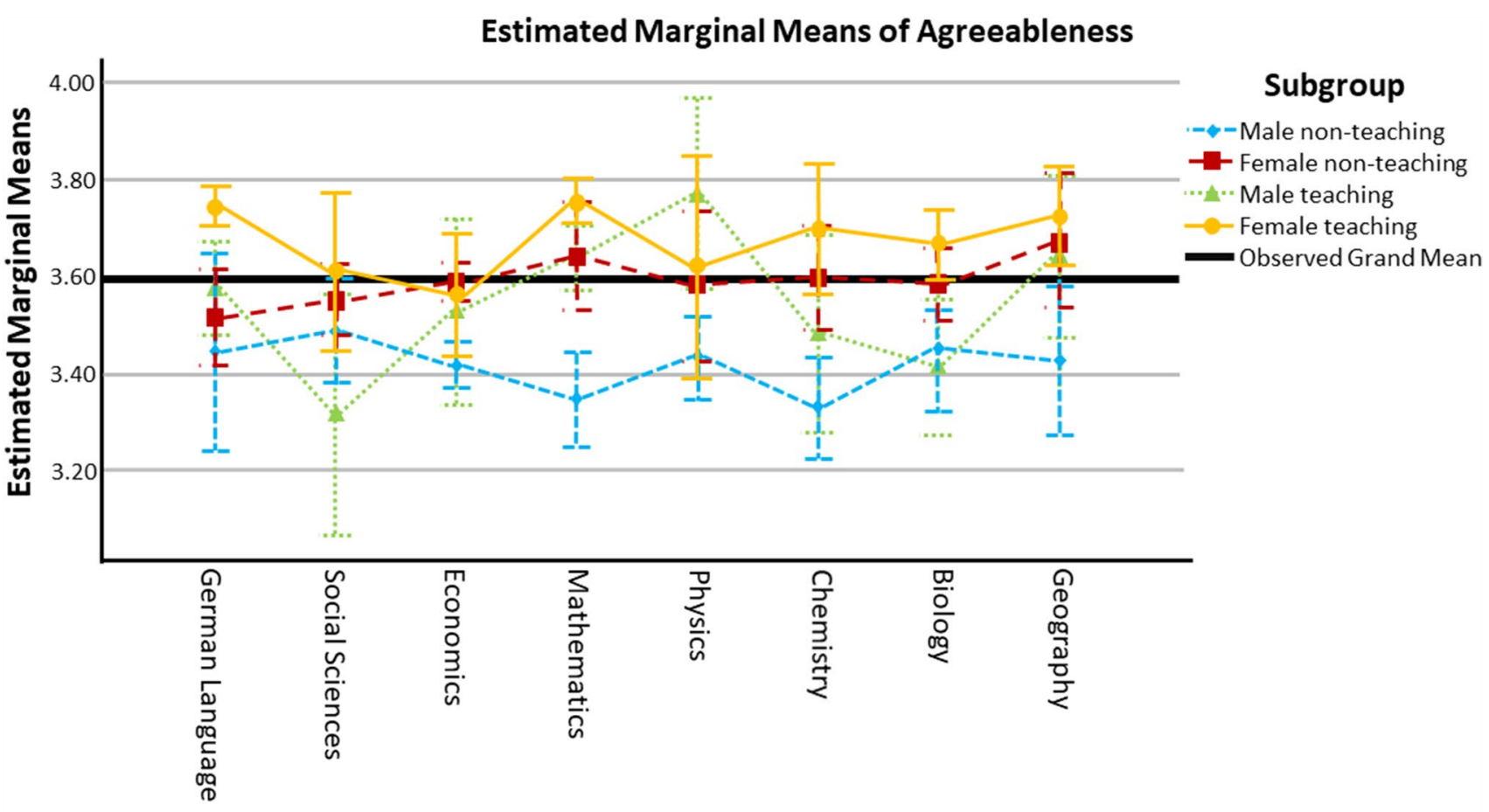

First Study Subject

Error bars: $95 \% \mathrm{Cl}$

Fig. 4 Means and 95\% confidence intervals for the students' agreeableness, for male non-teaching students (blue short dashed line), female non-teaching students (red long dashed line), male teacher candidates (green dotted line), and female teacher candidates (orange solid line) in the different subjects $(\min =1 ; \max =5)$. Tables with the respective values can be found in Supplement 4
These contrasts are likely to blur when academic majors are grouped into a few broad categories such as STEM and non-STEM.

In summary, gender was particularly related to the personality factors of neuroticism and conscientiousness, with female students scoring higher than male students. The study program (teacher vs. non-teacher) was clearly related to extraversion, with teacher candidates being more extraverted than their non-teaching counterparts. Regarding academic major, substantial differences could be observed with respect to openness. Here, students in German showed particularly high scores. There were no substantial interactions observed between gender, study program, and academic major.

In contrast to previous studies, we differentiated eight academic majors when investigating the personality traits of teacher candidates. Using this analytic strategy, personality trait differences between STEM and non-STEM teacher candidates could be observed. More importantly, differences between STEM and non-STEM teacher candidates with respect to the same Big Five dimension did not always point in the same direction.

\section{Discussion}

The personality traits of teacher candidates were examined across eight different majors using data from a large-scale study. To reveal teacher-specific characteristics, teacher candidates were compared to students who studied the same major but who were not aspiring to enter the teaching profession. In addition to study program (teachers vs. non-teacher) and academic major, gender was taken into account when investigating students' scores on the Big Five dimensions.

With respect to the study program (teachers vs. nonteachers), this study sheds light on the question of whether the "right" people choose to become teachers. In line with previous research (Klusmann et al., 2009; Roloff Henoch et al., 2015), our results do not confirm the often-discussed negative selection hypothesis. Against the background of how the Big Five are related to academic and career success (Judge et al., 2002; Koschmieder et al., 2018; Ng et al., 2005; Ng \& Feldman, 2014; Poropat, 2009; Richardson et al., 2012; Trapmann et al., 2007; Vedel \& Poropat, 


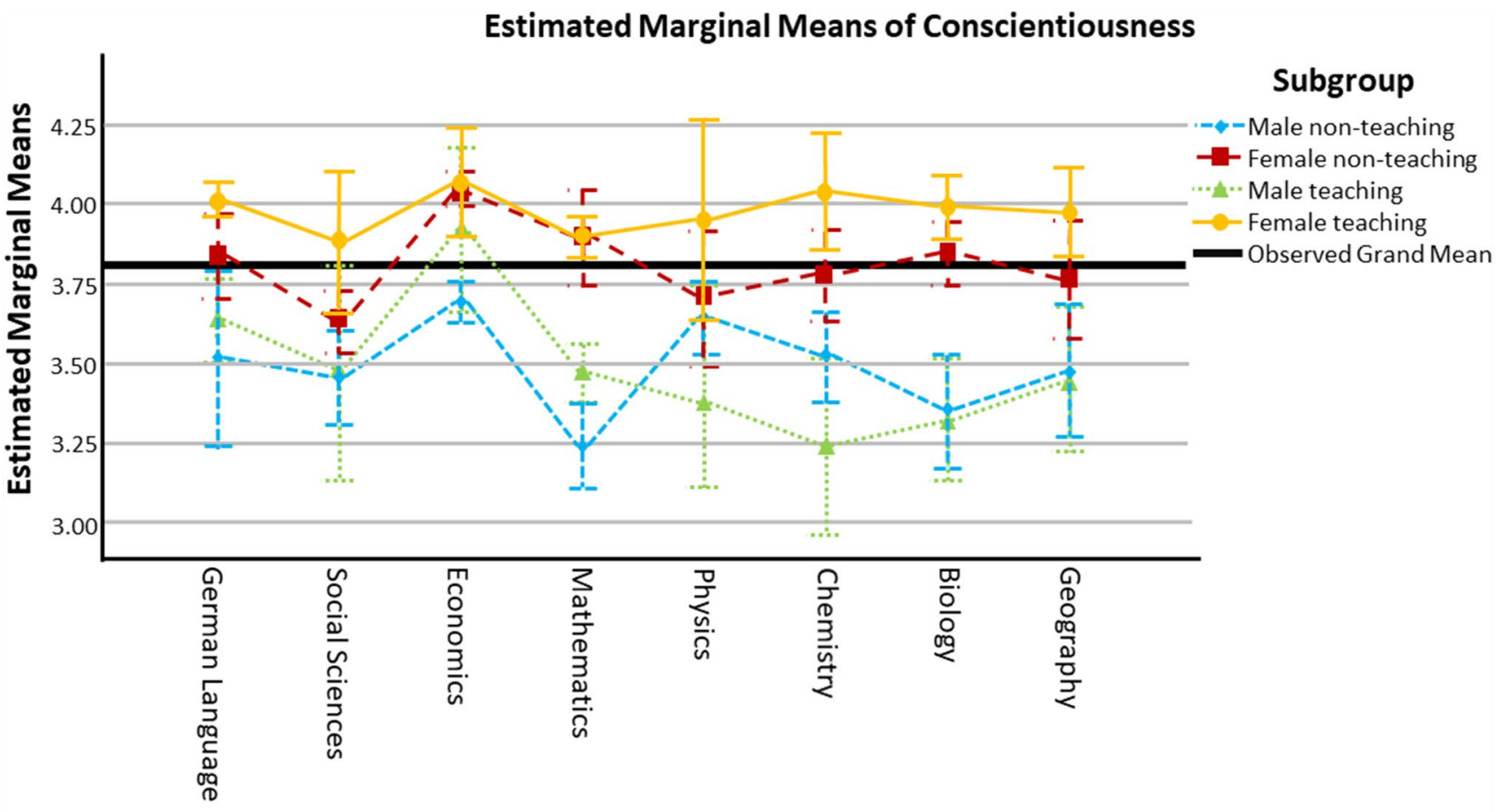

First Study Subject

Error bars: $95 \% \mathrm{Cl}$

Fig. 5 Means and 95\% confidence intervals for the students' conscientiousness, for male non-teaching students (blue short dashed line), female non-teaching students (red long dashed line), male teacher

2017) and the recurrently found resilient personality type (Asendorpf et al., 2001; De Fruyt, 2002; van der Wal et al., 2016; Semeijn et al., 2020), teachers across different academic majors do not show unfavorable personality traits in comparison to other students. The clearest personality trait differences between teacher candidates and non-teaching students could be observed regarding extraversion, with teacher candidates showing higher scores across several different academic majors. In this respect, teacher candidates show comparatively favorable personality characteristics, hopefully promoting the development of teacher effectiveness and reducing the risk of burnout as a result (Baier et al., 2019; Kim et al., 2019).

Results regarding majors are in line with previous systematic reviews (Vedel, 2016), with openness being the Big Five dimension with the strongest relation to the academic field. The current study differentiated eight different majors when analyzing the personality traits of teacher candidates. This analytic strategy stands in contrast to the approach used in previous research that grouped very diverse academic majors into broad categories such as the STEM and non-STEM (Roloff Henoch et al., 2015). It has been shown in several investigations that this approach is likely to blur major-specific differences when studying students' candidates (green dotted line), and female teacher candidates (orange solid line) in the different subjects $(\min =1 ; \max =5)$. Tables with the respective values can be found in Supplement 5

dispositional characteristics (Ertl \& Hartmann, 2019; Su \& Rounds, 2015). This was confirmed by the results of the current investigation with respect to teacher candidates in different STEM and non-STEM majors. For example, female teacher candidates in the STEM fields of math and chemistry scored lower on openness than female teacher candidates in the non-STEM field of German language. In contrast, female teacher candidates in the STEM fields of physics and biology scored higher on openness than female teacher candidates in the non-STEM field of economics. So STEM teacher candidates and non-STEM teacher candidates differ in varying directions depending on which specific STEM and non-STEM majors are compared. In addition to different directions regarding personality trait differences between STEM and non-STEM teacher candidates, there are also more major-specific peculiarities. For example, male and female teacher candidates in STEM majors such as math often showed differences to their non-STEM counterparts, while male and female teacher candidates in the STEM field of geography did not differ at all from teacher candidates in any non-STEM major. This questions the meaningfulness of grouping geography into the STEM category. Since some studies do not report what academic majors are grouped together, and since the grouping of academic majors can be 
done differently (e.g. social sciences assigned to STEM or not), the broad categories of STEM and non-STEM may be comprised of different academic majors. This hinders the accumulation of findings of different studies for meta-analysis and, in turn, the achievement of robust conclusions that go beyond single studies (Siddaway et al., 2019).

Gender differences found in the current study confirm the results of previous studies, with females reporting higher scores on the Big Five factors of neuroticism, openness, agreeableness, and conscientiousness (Rammstedt, 2007). According to previous studies, it can be assumed that these differences are mainly grounded in latent constructs and can only be traced in some part back to other reasons such as stereotypical response behavior (Ock et al., 2020). Future studies could investigate what effects these gender differences actually have on job-relevant outcomes in the teaching context, especially when all Big Five dimensions are taken into account.

Summarizing the results in the light of Person-Environment fit theories (e.g. Holland, 1997), choosing the environment of a teacher education program seems to be related to future teachers' personality traits. The results of the current study indicate that this relation is twofold: on one hand, the personality of teacher candidates in different subject areas is similarly linked to the teaching profession. Here, the trait of extraversion appears to be an especially crucial factor for enrolling in a teacher education program, since the scores in this Big Five dimensions were higher for teacher candidates in all subjects in comparison to students not intending to become a teacher. This corresponds to previous research (Barrick \& Mount, 1991; Mount et al., 1998) claiming that the Big Five dimension of extraversion is related to jobs emphasizing social interaction. At the same time, teacher candidates' personality seems to be linked to their specific subject areas. In line with the systematic review of Vedel (2016), the clearest differences between teacher candidates in different subject areas could be observed regarding the Big Five dimension of openness, with teacher candidates in German and physics showing high scores and teacher candidates in economics showing relatively low scores. The practical implication of this finding relates to the design of teacher education programs (c.f. Darling-Hammond et al., 2005). Openness to new experience predicts favorable outcomes such as the appreciation of human universality and diversity (Han \& Pistole, 2017; Thompson et al., 2002). Since student diversity increases all over the world, this is a crucial attitude for future teachers that needs to be addressed in teacher education (Ambe, 2006; Maasum et al., 2014; UNESCO, 2004; Yang \& Montgomery, 2013). More accurately, teacher education programs should include diversity courses or workshops (see Engberg, 2004; Gorski, 2009; Smith, 2020), and based on the results of the current study, especially for those subject areas that attract teacher candidates with low scores on the Big Five dimension of openness.

\section{Limitations and Future Directions}

Future studies should investigate to what extent personality trait differences between teachers from different majors actually lead to different outcomes and influence the development of teachers' professional competence, teacher health, and student performance through the different use of learning opportunities (Kunter et al., 2013a, 2013b). In addition, the current study's limitations could motivate future investigations. For example, the scale of agreeableness showed rather low internal consistency, questioning the reliability of the personality trait scores with respect to this personality factor. Big Five dimensions were measured highly economically within the framework of a large-scale study (c.f. Ertl et al., 2020) with only two items per scale (with the exception of agreeableness). Future studies could apply other instruments to assess personality traits comprising of more items, achieving a higher reliability, and enabling latent variable approaches such as structural equation modeling (Kline, 2016). Beyond this, using other instruments like the NEO-PI-R (Costa Jr. \& McCrae, 1992) would enable the different facets of the Big Five dimensions to be taken into account. Different facets become even more important when the effects of personality traits are investigated because some facets are more relevant than others with regard to academic and career outcomes (Gatzka \& Hell, 2018; Judge et al., 2013). This study used the Big Five framework and carried out a variable-centered analysis. Future studies could additionally use different frameworks such as the HEXACO model or the Dark Triad of personality to shed a different light on teacher candidates' personalities (c.f. Vedel \& Thomsen, 2017). Although the variable-centered approach is useful for studying personality traits and their related effects, future studies could also apply a person-centered approach, analyzing the personality profiles of teacher candidates to contribute to a more holistic picture of personality traits in the teaching context (Perera et al., 2018).

\section{Conclusions}

This paper analyzed personality profiles for different subject areas based on the Big Five personality structure (John et al., 2008). While much is known about personality profiles with respect to vocational interests (e.g. Holland, 1997) and while this knowledge has produced several classification schemes for career counseling postulating fits between occupations and specific interests (Nauta, 2010), evidence based on the Big Five personality dimensions 
has led to less clear practical implications so far. For example, counseling tools such as the General Interest Structure Test (Bergmann \& Eder, 2019), which is based on Holland's Self-Directed Search (Holland et al., 1994), suggests a specific configuration of vocational interests regarding the job of a teacher in economics (i.e. strong enterprising, conventional, and social interests), and such information is lacking regarding the Big Five personality traits. This paper revealed notable differences in the Big Five personality variables for students of different gender, different subject areas, and different study programs. Evidence from this paper could thereby serve as a starting point for a systematization of personality affordances for occupations using the Big Five framework, since Big Five personality traits and vocational interests are not interchangeable but represent distinct constructs (Hurtado Rúa et al., 2019) that may predict different career outcomes.

Although the results could be used in the recruitment of teachers, we recommend a cautious and thoughtful use of the findings. They should be used more in an effort to promote individual development, and less for the selection of teacher candidates (American Educational Research Association, 2015; Kim et al., 2019). For example, it may be misleading to try to select only people scoring high on extraversion. Qualitative analyzes can examine what strategies could be used to make up for a lack in a favorable personality trait (Chuhran, 2020) so that students even benefit from it when they are e.g. encouraged to be the focus of the classroom instead of the teacher (Mayr, 2016). This kind of perspective promotes diversity among teaching staffs and can help teachers find their individual pathways by using their personal characteristics in order to become good at their profession (Schnitzius et al., 2019). So it's not only important to choose the "right people" but also to provide the right teacher education that responds to some degree to the individual characteristics of teacher candidates (Mayr, 2016). Finally, a more complex and open view of favorable characteristics may arise when the effects of teacher candidates' personalities on student outcomes are investigated by also taking students' personality into account.

Supplementary Information The online version contains supplementary material available at https://doi.org/10.1007/s12144-021-02528-3.

Acknowledgements (1) This paper uses data from the National Educational Panel Study (NEPS): Starting Cohort First-Year Students, https:// doi.org/10.5157/NEPS:SC5:12.0.0. From 2008 to 2013, NEPS data was collected as part of the Framework Program for the Promotion of Empirical Educational Research funded by the German Federal Ministry of Education and Research (BMBF). As of 2014, NEPS is carried out by the Leibniz Institute for Educational Trajectories (LIfBi) at the University of Bamberg in cooperation with a nationwide network.

(2) We would like to thank Diana Lee Sosa for the language revision of this paper.
Authors' Contributions All authors listed have made a substantial, direct and intellectual contribution to the work, and have approved it for publication.

Funding Open Access funding enabled and organized by Projekt DEAL. This project was partially funded by the Deutsche Forschungsgemeinschaft (DFG, German Research Foundation) - ER470/2-1.

Data Availability Data used are available to the scientific community as scientific use files (see acknowledgements above).

Code Availability IBM SPSS Statistics (Version 25) was used for all of the statistical analyses.

\section{Declarations}

Ethics Statement Data sources used for the analyses were the cohort of first year students (SC5:12.0.0) of the German National Educational Panel Study (Blossfeld et al., 2011). All students of this cohort gave informed consent for participating in the panel. All data analyses were performed via a remote terminal (RemoteNEPS) at LIfBi in Bamberg that provides a controlled privacy environment for data access.

Conflicts of Interest The authors declare that this research was conducted in the absence of any personal, commercial or financial relationships that could be construed as potential conflicts of interest.

Open Access This article is licensed under a Creative Commons Attribution 4.0 International License, which permits use, sharing, adaptation, distribution and reproduction in any medium or format, as long as you give appropriate credit to the original author(s) and the source, provide a link to the Creative Commons licence, and indicate if changes were made. The images or other third party material in this article are included in the article's Creative Commons licence, unless indicated otherwise in a credit line to the material. If material is not included in the article's Creative Commons licence and your intended use is not permitted by statutory regulation or exceeds the permitted use, you will need to obtain permission directly from the copyright holder. To view a copy of this licence, visit http://creativecommons.org/licenses/by/4.0/.

\section{References}

Abbott, M. (2017). Using statistics in the social and health sciences with SPSS and excel. Wiley.

Ambe, E. B. (2006). Fostering multicultural appreciation in pre-service teachers through multicultural curricular transformation. Teaching and Teacher Education, 22(6), 690-699. https://doi.org/10. 1016/j.tate.2006.03.005

American Educational Research Association. (2015). AERA statement on use of value-added models (VAM) for the evaluation of educators and educator preparation programs. Educational Researcher, 44(8), 448-452. https://doi.org/10.3102/0013189X15618385

Angleitner, A., Ostendorf, F., \& John, O. P. (1990). Towards a taxonomy of personality descriptors in German: A psycho-lexical study. European Journal of Personality, 4(2), 89-118. https:// doi.org/10.1002/per.2410040204

Anušić, I., \& Schimmack, U. (2016). Stability and change of personality traits, self-esteem, and well-being: Introducing the metaanalytic stability and change model of retest correlations. Journal of Personality and Social Psychology. https://doi.org/10.1037/ pspp0000066 
Asendorpf, J. B., Borkenau, P., Ostendorf, F., \& Aken, M. A. G. V. (2001). Carving personality description at its joints: Confirmation of three replicable personality prototypes for both children and adults. European Journal of Personality, 15(3), 169-198. https://doi.org/10.1002/per.408

Ashton, M. C., \& Lee, K. (2007). Empirical, theoretical, and practical advantages of the HEXACO model of personality structure. Personality and Social Psychology Review, 11(2), 150-166. https:// doi.org/10.1177/1088868306294907

Ashton, M. C., Lee, K., Perugini, M., Szarota, P., de Vries, R. E., Di Blas, L., Boies, K., \& De Raad, B. (2004). A six-factor structure of personality-descriptive adjectives. Solutions from psycholexical studies in seven languages. Journal of Personality and Social Psychology, 86(2), 356-366. https://doi.org/10.1037/0022-3514. 86.2.356

Ayaita, A. \& Stürmer, K. (2019). Risk aversion and the teaching profession: An analysis including different forms of risk aversion, different control groups, selection and socialization effects, SOEPpapers on Multidisciplinary Panel Data Research, No. 1057, German Institute for Economic Research (DIW Berlin). Retrieved from https://www.diw.de/documents/publikationen/73/ diw_01.c.695666.de/diw_sp1057.pdf

Baier, F., Decker, A.-T., Voss, T., Kleickmann, T., Klusmann, U., \& Kunter, M. (2019). What makes a good teacher? The relative importance of mathematics teachers' cognitive ability, personality, knowledge, beliefs, and motivation for instructional quality. British Journal of Educational Psychology, 89(4), 767-786. https://doi.org/10.1111/bjep.12256

Barrick, M. R., \& Mount, M. K. (1991). The Big Five personality dimensions and job performance: A meta-analysis. Personnel Psychology, 44(1), 1-26. https://doi.org/10.1111/j.1744-6570. 1991.tb00688.x

Bastian, K. C., McCord, D. M., Marks, J. T., \& Carpenter, D. (2017). A temperament for teaching? Associations between personality traits and beginning teacher performance and retention. AERA Open, 3(1), 2332858416684764. https://doi.org/10.1177/23328 58416684764

Bergmann, C., \& Eder, F. (2019). AIST 3. Allgemeiner InteressenStruktur-Test mit Umwelt-Struktur-Test (UST) - Version 3 [AIST 3. General interest structure test and environmental structure test - Version 3]. Beltz.

Blossfeld, H.-P., Roßbach, H.-G., \& von Maurice, J. (2011). Education as a lifelong process: The German National Educational Panel Study (NEPS). Zeitschrift für Erziehungswissenschaft Sonderheft, $14,330$.

Chuhran, K. (2020). Effective introvert teachers: A phenomenological study of their lived experiences [Concordia University, St. Paul]. https://digitalcommons.csp.edu/cup_commons_grad_edd/453

Cortina, K. S., \& Thames, M. H. (2013). Teacher education in Germany. In M. Kunter, J. Baumert, W. Blum, U. Klusmann, S. Krauss, \& M. Neubrand (Eds.), Cognitive activation in the mathematics classroom and professional competence of teachers: Results from the COACTIV project (pp. 49-62). Springer US. https://doi.org/10.1007/978-1-4614-5149-5_3

Costa Jr., P. T., \& McCrae, R. R. (1989). NEO PI/FFI manual supplement. Psychological Assessment Resources.

Costa Jr., P. T., \& McCrae, R. R. (1992). NEO PI-R professional manual. Psychological Assessment Resources.

Costa, P. T., McCrae, R. R., \& Löckenhoff, C. E. (2019). Personality across the life span. Annual Review of Psychology, 70(1), 423-448. https://doi.org/10.1146/annurev-psych-010418-103244

Cronbach, L. J. (1951). Coefficient alpha and the internal structure of tests. Psychometrika, 16(3), 297-334. https://doi.org/10.1007/ BF02310555

Danner, D., Rammstedt, B., Bluemke, M., Lechner, C., Berres, S., Knopf, T., Soto, C. J., \& John, O. P. (2019). Das Big Five
Inventar 2. Validierung eines Persönlichkeitsinventars zur Erfassung von 5 Persönlichkeitsdomänen und 15 Facetten [The German Big Five Inventory 2: Measuring five personality domains and 15 facets]. Diagnostica, 65(3), 121-132. https://doi.org/10. 1026/0012-1924/a000218

Darling-Hammond, L., Hammerness, K., Grossman, P., Rust, F., \& Shulman, L. (2005). The design of teacher education programs. In L. Darling-Hammond \& J. Bransford (Eds.), Preparing teachers for a changing world: What teachers should learn and be able to do (pp. 390-441). Jossey-Bass.

De Fruyt, F. (2002). A person-centered approach to p-e fit questions using a multiple-trait model. Journal of Vocational Behavior, 60(1), 73-90. https://doi.org/10.1006/jvbe.2001.1816

De Haro, J. M., Castejon, J. L., \& Gilar, R. (2020). Personality and salary at early career: The mediating effect of emotional intelligence. The International Journal of Human Resource Management, 31(14), 1844-1862. https://doi.org/10.1080/09585192. 2017.1423365

Engberg, M. E. (2004). Improving intergroup relations in higher education: A critical examination of the influence of educational interventions on racial bias. Review of Educational Research, 74(4), 473-524. https://doi.org/10.3102/00346543074004473

Ertl, B., \& Hartmann, F. G. (2019). The interest profiles and interest congruence of male and female students in STEM and NonSTEM fields. Frontiers in Psychology. https://doi.org/10.3389/ fpsyg.2019.00897

Ertl, B., Hartmann, F. G., \& Heine, J.-H. (2020). Analyzing largescale studies: Benefits and challenges. Frontiers in Psychology. https://doi.org/10.3389/fpsyg.2020.577410

Fauth, B., Decristan, J., Decker, A.-T., Büttner, G., Hardy, I., Klieme, E., \& Kunter, M. (2019). The effects of teacher competence on student outcomes in elementary science education: The mediating role of teaching quality. Teaching and Teacher Education, 86, 102882. https://doi.org/10.1016/j.tate.2019.102882

FDZ-LIfBi. (2020). Data manual NEPS Starting Cohort 5 - Firstyear students, From higher education to the labor market, Scientific Use File version 14.0.0. Bamberg, Germany: Leibniz Institute for Educational Trajectories, National Educational Panel Study.

Feingold, A. (1994). Gender differences in personality: A meta-analysis. Psychological Bulletin, 116(3), 429-456. https://doi.org/10. 1037/0033-2909.116.3.429

Field, A., Miles, J., \& Field, Z. (2019). Discovering statistics using SPSS (5th ed.). Sage.

Furnham, A., Guenole, N., Levine, S. Z., \& Chamorro-Premuzic, T. (2013). The NEO personality inventory-revised: Factor structure and gender invariance from exploratory structural equation modeling analyses in a high-stakes setting. Assessment, 20(1), 14-23. https://doi.org/10.1177/1073191112448213

Gatzka, T., \& Hell, B. (2018). Openness and postsecondary academic performance: A meta-analysis of facet-, aspect-, and dimensionlevel correlations. Journal of Educational Psychology, 110(3), 355-377. https://doi.org/10.1037/edu0000194

Goldberg, L. R. (1990). An alternative "description of personality": The Big-Five factor structure. Journal of Personality and Social Psychology, 59(6), 1216-1229. https://doi.org/10.1037/00223514.59.6.1216

Göncz, L. (2017). Teacher personality: A review of psychological research and guidelines for a more comprehensive theory in educational psychology. Open Review of Educational Research, 4(1), 75-95. https://doi.org/10.1080/23265507.2017.1339572

Gorski, P. C. (2009). What we're teaching teachers: An analysis of multicultural teacher education coursework syllabi. Teaching and Teacher Education, 25(2), 309-318. https://doi.org/10.1016/j. tate.2008.07.008 
Han, S., \& Pistole, M. C. (2017). Big five personality factors and facets as predictors of openness to diversity. The Journal of Psychology, 151(8), 752-766. https://doi.org/10.1080/00223980.2017. 1393377

Holland, J. L. (1997). Making vocational choices. A theory of vocational personalities and work environments (3rd ed.). Psychological Assessment Resources.

Holland, J. L., Fritzsche, B. A., \& Powell, A. B. (1994). The selfdirected search technical manual. Psychological Assessment Resources.

Hurtado Rúa, S. M., Stead, G. B., \& Poklar, A. E. (2019). Five-factor personality traits and RIASEC interest types: A multivariate meta-analysis. Journal of Career Assessment, 27(3), 527-543. https://doi.org/10.1177/1069072718780447

Javaras, K. N., Williams, M., \& Baskin-Sommers, A. R. (2019). Psychological interventions potentially useful for increasing conscientiousness. Personality Disorders: Theory, Research, and Treatment, 10(1), 13-24. https://doi.org/10.1037/per0000267

John, O. P., Donahue, E. M., \& Kentle, R. L. (1991). The big five inventory-Versions $4 a$ and 54. University of California, Berkeley, Institute of Personality and Social Research.

John, O. P., Naumann, L. P., \& Soto, C. J. (2008). Paradigm shift to the integrative big five trait taxonomy: History, measurement, and conceptual issues. In O. P. John, R. W. Robins, \& L. A. Pervin (Eds.), Handbook of personality: Theory and research (pp. 114-158). The Guilford Press.

Judge, T., \& Kammeyer-Mueller, J. (2007). Personality and career success. In H. Gunz \& M. Peiperl (Eds.), The SAGE handbook of personality and individual differences: Applications of personality and individual differences (pp. 537-551). SAGE Publications. https://doi.org/10.4135/9781526451248.n23

Judge, T. A., Heller, D., \& Mount, M. K. (2002). Five-factor model of personality and job satisfaction: A meta-analysis. Journal of Applied Psychology, 87(3), 530-541. https://doi.org/10.1037/ 0021-9010.87.3.530

Judge, T. A., Rodell, J. B., Klinger, R. L., Simon, L. S., \& Crawford, E. R. (2013). Hierarchical representations of the five-factor model of personality in predicting job performance: Integrating three organizing frameworks with two theoretical perspectives. Journal of Applied Psychology, 98(6), 875-925. https://doi.org/10. 1037/a0033901

Kajonius, P. J., \& Johnson, J. (2018). Sex differences in 30 facets of the five factor model of personality in the large public $(\mathrm{N}=320,128)$. Personality and Individual Differences, 129, 126-130. https:// doi.org/10.1016/j.paid.2018.03.026

Kaub, K., Karbach, J., Spinath, F. M., \& Brünken, R. (2016). Personjob fit in the field of teacher education - An analysis of vocational interests and requirements among novice and professional science and language teachers. Teaching and Teacher Education, 55, 217-227. https://doi.org/10.1016/j.tate.2016.01.010

Kaufman, J. C., Pumaccahua, T. T., \& Holt, R. E. (2013). Personality and creativity in realistic, investigative, artistic, social, and enterprising college majors. Personality and Individual Differences, 54(8), 913-917. https://doi.org/10.1016/j.paid.2013.01.013

Kim, L. E., Jörg, V., \& Klassen, R. M. (2019). A meta-analysis of the effects of teacher personality on teacher effectiveness and burnout. Educational Psychology Review, 31(1), 163-195. https://doi. org/10.1007/s10648-018-9458-2

Klassen, R. M., \& Kim, L. E. (2019). Selecting teachers and prospective teachers: A meta-analysis. Educational Research Review, 26, 32-51. https://doi.org/10.1016/j.edurev.2018.12.003

Klassen, R., Durksen, T. L., Kim, L., Patterson, F., Rowett, E., Warwick, J., Warwick, P., \& Wolpert, M. (2017). Developing a proofof-concept selection test for entry into primary teacher education programs. International Journal of Assessment Tools in Education, 4(2), 96-114. 10.21449/ijate.275772.

Kline, R. B. (2016). Principles and practice of structural equation modeling (Fourth ed.). The Guilford Press.

Klusmann, U., Trautwein, U., Lüdtke, O., Kunter, M., \& Baumert, J. (2009). Eingangsvoraussetzungen beim Studienbeginn: Werden die Lehramtskandidaten unterschätzt? Zeitschrift für Pädagogische Psychologie, 23(34), 265-278. https://doi.org/10.1024/ 1010-0652.23.34.265

Koschmieder, C., Weissenbacher, B., Pretsch, J., \& Neubauer, A. C. (2018). The impact of personality in the selection of teacher students: Is there more to it than the big five? Europe's Journal of Psychology, 14(3), 680-694. https://doi.org/10.5964/ejop.v14i3. 1536

Kunter, M., Kleickmann, T., Klusmann, U., \& Richter, D. (2013a). The development of teachers' professional competence. In M. Kunter, J. Baumert, W. Blum, U. Klusmann, S. Krauss, \& M. Neubrand (Eds.), Cognitive activation in the mathematics classroom and professional competence of teachers (pp. 63-77). Springer U.S.

Kunter, M., Klusmann, U., Baumert, J., Richter, D., Voss, T., \& Hachfeld, A. (2013b). Professional competence of teachers: Effects on instructional quality and student development. Journal of Educational Psychology, 105(3), 805-820. https://doi.org/ 10.1037/a0032583

Leon, A., Behrendt, S., \& Nickolaus, R. (2018). Interessenstrukturen von Studierendenden unterschiedlicher Fachrichtungen und damit verbundene Potentiale für die Gewinnung von Lehramtsstudierenden. Journal of Technical Education (JOTED), 6(2), $39-54$.

Litten, V., Roberts, L. D., Ladyshewsky, R. K., Castell, E., \& Kane, R. (2020). Empathy and psychopathic traits as predictors of selection into business or psychology disciplines. Australian Journal of Psychology, 72(1), 93-105. https://doi.org/10.1111/ajpy.12263

Low, K. S. D., Yoon, M., Roberts, B. W., \& Rounds, J. (2005). The stability of vocational interests from early adolescence to middle adulthood: A quantitative review of longitudinal studies. Psychological Bulletin, 131(5), 713-737. https://doi.org/10.1037/ 0033-2909.131.5.713

Maasum, T. N. R. T. M., Maarof, N., \& Ali, M. M. (2014). Addressing student diversity via culturally responsive pedagogy. Procedia Social and Behavioral Sciences, 134, 101-108. https://doi.org/ 10.1016/j.sbspro.2014.04.227

Mayr, J. (2016). Lehrerpersönlichkeit [teacher personality]. In M. Rothland (Ed.), Beruf Lehrer/Lehrerin. Ein Studienbuch (pp. 87-102). Münster, Germany.

McAbee, S. T., \& Oswald, F. L. (2013). The criterion-related validity of personality measures for predicting GPA: A meta-analytic validity competition. Psychological Assessment, 25(2), 532-544. https://doi.org/10.1037/a0031748

McCrae, R. R., \& John, O. P. (1992). An introduction to the five-factor model and its applications. Journal of Personality, 60(2), 175215. https://doi.org/10.1111/j.1467-6494.1992.tb00970.x

McCrae, R. R., Kurtz, J. E., Yamagata, S., \& Terracciano, A. (2011). Internal consistency, retest reliability, and their implications for personality scale validity. Personality and Social Psychology Review : An Official Journal of the Society for Personality and Social Psychology, Inc, 15(1), 28-50. https://doi.org/10.1177/ 1088868310366253

Mount, M. K., Barrick, M. R., \& Stewart, G. L. (1998). Five-factor model of personality and performance in jobs involving interpersonal interactions. Human Performance, 11(2-3), 145-165. https://doi.org/10.1080/08959285.1998.9668029

Nauta, M. M. (2010). The development, evolution, and status of Holland's theory of vocational personalities: Reflections and future 
directions for counseling psychology. Journal of Counseling Psychology, 57(1), 11-22. https://doi.org/10.1037/a0018213

Ng, T. W. H., \& Feldman, D. C. (2014). Subjective career success: A meta-analytic review. Journal of Vocational Behavior, 85(2), 169-179. https://doi.org/10.1016/j.jvb.2014.06.001

Ng, T. W. H., Eby, L. T., Sorensen, K. L., \& Feldman, D. C. (2005). Predictors of objective and subjective career success: A metaanalysis. Personnel Psychology, 58(2), 367-408. https://doi.org/ 10.1111/j.1744-6570.2005.00515.x

Nguyen, T.-L. K., Williams, A., \& Ludwikowski, W. M. A. (2016). Predicting student success and retention at an HBCU via interest-major congruence and academic achievement. Journal of Career Assessment, 25(3), 552-566. https://doi.org/10.1177/ 1069072716651870

O*NET (2020). O*NET® 24.1 Database. Interests [xls]. Retrieved from https://www.onetcenter.org/dictionary/24.1/excel/interests. html

Ock, J., McAbee, S. T., Mulfinger, E., \& Oswald, F. L. (2020). The practical effects of measurement invariance: Gender invariance in two big five personality measures. Assessment, 27(4), 657-674. https://doi.org/10.1177/1073191119885018

Ostendorf, F. (1990). Sprache und Persönlichkeitsstruktur. Zur Validität des Fünf-Faktoren-Modells der Persönlichkeit [Language and personality structure. On the validity of the five factor model of personality]. : S. Roderer Verlag.

Paulhus, D. L., \& Williams, K. M. (2002). The dark triad of personality: Narcissism, machiavellianism, and psychopathy. Journal of Research in Personality, 36, 556-563. https://doi.org/10.1016/ S0092-6566(02)00505-6

Perera, H. N., Granziera, H., \& McIlveen, P. (2018). Profiles of teacher personality and relations with teacher self-efficacy, work engagement, and job satisfaction. Personality and Individual Differences, 120, 171-178. https://doi.org/10.1016/j.paid.2017.08.034

Poropat, A. E. (2009). A meta-analysis of the five-factor model of personality and academic performance. Psychological Bulletin, 135(2), 322-338. https://doi.org/10.1037/a0014996

Pretsch, J., Flunger, B., \& Schmitt, M. (2012). Resilience predicts wellbeing in teachers, but not in non-teaching employees. Social Psychology of Education, 15(3), 321-336. https://doi.org/10.1007/ s11218-012-9180-8

Rammstedt, B. (2007). The 10-item big five inventory: Norm values and investigation of sociodemographic effects based on a German population representative sample. European Journal of Psychological Assessment, 23(3), 193-201. https://doi.org/10. 1027/1015-5759.23.3.193

Rammstedt, B., \& John, O. P. (2007). Measuring personality in one minute or less: A 10-item short version of the big five inventory in English and German. Journal of Research in Personality, 41(1), 203-212. https://doi.org/10.1016/j.jrp.2006.02.001

Rammstedt, B., Kemper, C. J., Klein, M. C., Beierlein, C., \& Kovaleva, A. (2014). Big Five Inventory (BFI-10). Zusammenstellung sozialwissenschaftlicher Items und Skalen (ZIS). : GESIS. doi: https://doi.org/10.6102/ZIS76.

Richardson, M., Abraham, C., \& Bond, R. (2012). Psychological correlates of university students' academic performance: A systematic review and meta-analysis. Psychological Bulletin, 138(2), 353-387. https://doi.org/10.1037/a0026838

Roloff Henoch, J., Klusmann, U., Lüdtke, O., \& Trautwein, U. (2015). Who becomes a teacher? Challenging the "negative selection" hypothesis. Learning and Instruction, 36, 46-56. https://doi.org/ 10.1016/j.learninstruc.2014.11.005
Roloff, J., Klusmann, U., Lüdtke, O., \& Trautwein, U. (2020). The predictive validity of teachers' personality, cognitive and academic abilities at the end of high school on instructional quality in Germany: A longitudinal study. AERA Open, 6(1), 1-17. https://doi. org/10.1177/2332858419897884

Samuel, D. B., South, S. C., \& Griffin, S. A. (2015). Factorial invariance of the five-factor model rating form across gender. Assessment, 22(1), 65-75. https://doi.org/10.1177/1073191114536772

Schnitzius, M., Kirch, A., Mess, F., \& Spengler, S. (2019). Inside out: A scoping review on the physical education teacher's personality. Frontiers in Psychology, 10. https://doi.org/10.3389/fpsyg. 2019.02510

Seibert, S. E., \& Kraimer, M. L. (2001). The five-factor model of personality and career success. Journal of Vocational Behavior, 58(1), 1-21. https://doi.org/10.1006/jvbe.2000.1757

Semeijn, J. h., van der Heijden, B. I. J. M., \& De Beuckelaer, A. (2020). Personality traits and types in relation to career success: An empirical comparison using the big five. Applied Psychology, 69(2), 538-556. https://doi.org/10.1111/apps.12174

Siddaway, A. P., Wood, A. M., \& Hedges, L. V. (2019). How to do a systematic review: A best practice guide for conducting and reporting narrative reviews, meta-analyses, and meta-syntheses. Annual Review of Psychology, 70(1), 747-770. https://doi.org/ 10.1146/annurev-psych-010418-102803

Smith, D. G. (2020). Diversity's promise for higher education: Making it work. JHU Press.

Su, R., \& Rounds, J. (2015). All STEM fields are not created equal: People and things interests explain gender disparities across STEM fields. Frontiers in Psychology, 6, 189. https://doi.org/ 10.3389/fpsyg.2015.00189

Su, R., Murdock, C., \& Rounds, J. (2015). Person-environment fit. In P. J. Hartung, M. L. Savickas, \& W. B. Walsh (Eds.), APA handbook of career intervention, Volume 1: Foundations (pp. 81-98). American Psychological Association. https://doi.org/10. 1037/14438-005

Thompson, R. L., Brossart, D. F., Carlozzi, A. F., \& Miville, M. L. (2002). Five-factor model (big five) personality traits and universal-diverse orientation in counselor trainees. The Journal of Psychology, 136(5), 561-572. https://doi.org/10.1080/00223 980209605551

Trapmann, S., Hell, B., Hirn, J.-O. W., \& Schuler, H. (2007). Metaanalysis of the relationship between the big five and academic success at university. Journal of Psychology, 215(2), 132-151. https://doi.org/10.1027/0044-3409.215.2.132

UNESCO. (2004). Changing teaching practices: Using curriculum differentiation to respond to students' diversity. UNESCO.

van der Wal, R. A. B., Bucx, M. J. L., Hendriks, J. C. M., Scheffer, G.-J., \& Prins, J. B. (2016). Work stress and satisfaction in relation to personality profiles in a sample of Dutch anaesthesiologists. European Journal of Anaesthesiology, 33(11), 800-806. https://doi.org/10.1097/EJA.0000000000000524

Vedel, A. (2016). Big five personality group differences across academic majors: A systematic review. Personality and Individual Differences, 92, 1-10. https://doi.org/10.1016/j.paid.2015.12.011

Vedel, A., \& Poropat, A. E. (2017). Personality and academic performance. In V. Zeigler-Hill \& T. K. Shackelford (Eds.), Encyclopedia of personality and individual differences (pp. 1-9). Springer International Publishing. https://doi.org/10.1007/978-3-31928099-8_989-1

Vedel, A., \& Thomsen, D. K. (2017). The dark triad across academic majors. Personality and Individual Differences, 116, 86-91. https://doi.org/10.1016/j.paid.2017.04.030 
Wohlkinger, F., Ditton, H., von Maurice, J., Haugwitz, M., \& Blossfeld, H.-P. (2011). 10 motivational concepts and personality aspects across the life course. Zeitschrift für Erziehungswissenschaft, 14(2), 155. https://doi.org/10.1007/s11618-011-0184-5

Yang, Y., \& Montgomery, D. (2013). Gaps or bridges in multicultural teacher education: A Q study of attitudes toward student diversity. Teaching and Teacher Education, 30, 27-37. https://doi.org/ 10.1016/j.tate.2012.10.003

Zinn, S., Steinhauer, H. W., \& Aßmann, C. (2017). Samples, weights, and nonresponse: The student sample of the National
Educational Panel Study (wave 1 to 8) (NEPS survey paper no. 18). Leibniz Institute for Educational Trajectories, .

Publisher's Note Springer Nature remains neutral with regard to jurisdictional claims in published maps and institutional affiliations. 